\title{
化学量論組成原料粉体からのムライトセラミックスの焼結性と 機械的特性におよぼす前駆体調製プロセスの影響
}

\author{
熊澤 猛 $1^{*}$, 尾関 文仁 ${ }^{1}$, 鈴木 久男 ${ }^{2}$

\begin{abstract}
Influence of Powder Preparation Process of Stoichiometric Mullite on Sinterability and Mechanical Properties of Mullite Ceramics
\end{abstract}

Takeshi Kumazawa $^{1 *}$, Fumihito Ozeki ${ }^{1}$ and Hisao Suzuki ${ }^{2}$

Received 24 April 2019; Accepted 10 July 2019

\begin{abstract}
In this paper, three types of precursor powders with nominal composition of $3 \mathrm{Al}_{2} \mathrm{O}_{3} \cdot 2 \mathrm{SiO}_{2}$ (stoichiometric composition) were prepared from tetra-methyl ortho-silicate (TMOS) and aluminum i-propoxide or aluminum nitrate to investigate the influence of the precursor powders on the sinterability and the mechanical properties of the resulting mullite ceramics. The results showed that compositional homogeneity and the agglomeration state of the precursor powders have large effect on the crystallization behavior and the sinterability, because the amount of the transient $\mathrm{SiO}_{2}$ phase affected both the sinterability and the crystallization behavior. Precursor powder from TMOS and aluminum nitrate resulted in the lower sinterebility and the lower mechanical properties of the resulting mullite ceramics. On the other hand, mullite ceramics sintered from alkoxide-derived precursor powders exhibited relatively higher mechanical properties at higher temperatures. Finally, we successfully prepared mullite ceramics with stoichiometric composition and excellent high-temperature mechanical properties by tuning the processing conditions.
\end{abstract}

Keywords: Stoichimetric mullite, Sinterability, Mechanical property, Compositional homogeneity, Glassy phase.

\section{1. 緒言}

ムライトはシリカーアルミナ系において $1500^{\circ} \mathrm{C}$ 以上 の高温まで唯一安定な化合物であり, 酸化物としては融 点が $1800^{\circ} \mathrm{C}$ 以上と高く, 低膨張で, 高温で優れた特性 を示す材料であることが知られている[1-3]。そのため, 古くから現在に至るまでカオリンなどの天然鉱物である シリカーアルミナ原料を用いたムライト[4]は, 大気中高 温で使用される耐火物や保護管に代表される窯業製品の 重要な構成相として用いられてきた。

高純度ムライトセラミックスの高温での特性は, 電気 陰性度から推定されるように代表的な酸化物セラミック スであるアルミナと比較して共有結合性が強く, 高温で 変形の少ない構造材料の可能性がある[5]。しかし, 天然 原料であるカオリンなどを用いて製造されたムライトセ

1 美濃空業株式会社 技術研究所

（７ 475-0027 愛知県半田市亀崎北浦町 1-46）

Mino Ceramic Co., Ltd

(1-46 Kamezaki Kitaura-cho, Handa, Aichi 475-0027, Japan) 2 静岡大学工学部

( ₹ 432-8011 静岡県浜松市城北 3-5-1)

Shizuoka University

(3-51 Johoku, Hamamatsu, Shizuoka 432-8011, Japan)

* Corresponding Author kumazawa@mino-ceramic.co.jp
ラミックスは, 含まれる不純物などにより高温で急激に 強度低下することが報告されている 6,7$]$ 。そのため, 不 純物の少ない金属アルコキシドや金属塩などのさまざま な出発原料を用い, 高純度で化学量論組成の粉体を作製 し[8,9], ムライトセラミックスの高温機械特性に関する 研究が進められてきた[10-12]。中でも，アルミナ含有量 71.8 重量\%の化学量論組成ムライトは難焼結性ではある が, 加圧焼結することによりち密化した高純度のセラミッ クスとすることで, 炭化ケイ素セラミックスに匹敵する 高温特性を示すことが報告された[12]。

以上のような経緯から, 高純度粉体が得られる噴霧熱 分解法によりアルミナ含有量 60 78 重量\%のシリカーア ルミナ粉体を合成し, 仮焼・粉砕などの処理を経て成形 および焼結したムライト含有セラミックスについて, 焼 結性と高温での曲げ強度におよぼすアルミナ含有量の影 響を調べたところ以下のことが明らかになった[13]。す なわち, 焼結性は高温で生成するガラス相の量と分布に 大きな影響を受けることから，アルミナ含有量が低い組 成ほど低温でち密化が進む傾向を示した。室温と高温で の曲げ強度についてもアルミナ含有量に大きく依存し, 74 重量\%よりアルミナ含有量に富む組成で室温強度と比 較して高温強度が緩やかに低下する傾向を示した。一方, 化学量論組成よりもシリカに富む組成では, $1300^{\circ} \mathrm{C}$ 付近 
で一旦曲げ強度の上昇が見られ，さらに温度が上昇する と曲げ強度が急激に低下した。

この論文における X 線回折による結晶相の同定と電子 顕微鏡による微構造観察の結果から, アルミナ含有量が 化学量論組成よりアルミナ成分に富む 74 重量\%の場合に 得られたムライト含有セラミックスの構成相はムライト 単一相であり，74 重量\%よりアルミナ成分に富む組成で はムライトとコランダムが同定された。一方，74 重量\% よりシリカに富む組成ではムライト相に加えてシリカリッ チのガラスが同定された。すなわち高純度原料からのム ライトセラミックスの焼結性および高温での機械的特性 は，アルミナ含有量による粒界相の影響を大きく受けて いることがわかった。

以上の結果に加え, 高純度のムライト前駆体は出発原 料, 合成方法あるいは合成条件などによりムライトに至 るまでの結晶化過程が異なることが知られている $[14-$ 16]。すなわち, 金属アルコキシドを用いたムライト前駆 体粉体は, 加熱することにより $1000^{\circ} \mathrm{C} て ゙ \mathrm{Al}-\mathrm{Si}$ スピネル と呼ばれる中間相を経て $1200^{\circ} \mathrm{C}$ 付近で完全にムライト 化することが報告されている。そして, Okada らによれ ば硝酸アルミニウムとオルトケイ酸エチルを出発原料と して調製した溶液にアンモニア水を添加して得られたム ライト前駆体も $1000^{\circ} \mathrm{C}$ 付近でスピネル相を生成し, こ のスピネル相の化学組成は $\mathrm{SiO}_{2} \cdot 6 \mathrm{Al}_{2} \mathrm{O}_{3}$ に近いシリカ含 有量約 8 重量\%であり，化学量論組成に対してアルミナ に富む組成であることを示した[17]。この結果は，高純 度で組成が均質な原料粉体からムライトが結晶化する場 合でも，アルミナに富むスピネル相とシリカに富む非晶 質相の固相反応によりムライト化すると考えられた。

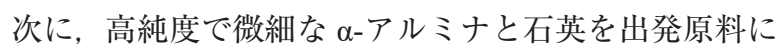
用て固相反応により化学量論組成のムライトを合成した 場合の昇温過程における結晶相の変化を調べた結果, 以 下のような事実がわかった。すなわち, 上述の原料をエ 夕ノール中で湿式混合し, 得られた原料を成形後, 大気 中で仮焼して結晶相を調べた $[18]$ 。その結果, $1470^{\circ} \mathrm{C} の$ 加熱によりムライト以外にコランダムとクリストバライ トが同定され，さらに高温に加熱するとムライトとコラ ンダムが同定された。したがって, 組成が均質でない原 料からのムライトセラミックスでは，ムライトの粒界に 大量のガラス相が残存するムライトセラミックスが得ら れた。

これらの結果より, 高純度で高均質なスピネル相を経 由してムライト化する方法で合成した化学量論組成ムラ イトセラミックスにおいても, 焼結過程においてムライ トの粒界に生成した液相が固化して生成したガラス相の 量に依存して, 高温での機械特性が影響を受けるものと 予想される。

そこで本研究では, 高純度原料を用いて作製した粉体 からムライト化に至るまでの中間生成物の生成量とムラ イト化温度が異なる前駆体粉体を用い, 原料粉体の合成 方法の違いが焼結性や高温での機械的性質におよぼす影 響について調べ，高温における化学量論組成ムライトセ
ラミックスの高温構造材料としての可能性について検討 を行った。

\section{2. 実験方法}

実験に用いたムライト前駆体粉体は，アルミニウムと シリコンのアルコキシド, および硝酸アルミニウムを出 発原料に用いて調製された北興化学工業社製粉体 (Ha 前 駆体粉体, $\mathrm{Hb}$ 前駆体粉体, $\mathrm{C}$ 前駆体粉体) を使用した。 調製方法は以下の通りである[19]。Ha 前駆体粉体では, アルミニウムイソプロポキシド $\left(\mathrm{Al}\left(\mathrm{OPr}^{\mathrm{i}}\right)_{3}\right)$ のベンゼン 溶液（濃度 $1 \mathrm{~mol} / \mathrm{L} ）$ とオルトケイ酸テトラメチル $\left(\mathrm{Si}(\mathrm{OMe})_{4}: \mathrm{TMOS}\right)$ のベンゼン溶液（濃度 $2 \mathrm{~mol} / \mathrm{L}$ ）を $\mathrm{Al}_{2} \mathrm{O}_{3}$ と $\mathrm{SiO}_{2}$ のモル比が 3 対 $2(\mathrm{Al}: \mathrm{Si}=6: 2)$ の化学量論 比になるように混合し, この混合溶液 $1 \mathrm{~L}$ をメ夕ノール $750 \mathrm{ml}$ と蒸留水 $1500 \mathrm{ml}$ の混合溶液にすばやく加え激し く擋挥し, $70 \sim 80^{\circ} \mathrm{C}$ で 3 時間加熱還流後ろ過して沈殿物 を回収した。

その後, $80^{\circ} \mathrm{C}$ で乾燥して $\mathrm{Ha}$ 前駆体粉体を得た。 $\mathrm{Hb}$ 前 駆体粉体では, 前述のベンゼン混合溶液にメタノール $750 \mathrm{ml}$ と $\mathrm{pH} 10$ に調整されたアンモニア水 $1500 \mathrm{ml}$ をす ばやく加え, 激しく擋汼して Ha 前駆体粉体と同一条件 で加熱還流し, ろ過および乾燥した。すなわち, Ha 前駆 体粉体と $\mathrm{Hb}$ 前駆体粉体の違いは加水分解触媒としてア ンモニア水を用いたかどうかであり, Hb 前駆体ではより TMOS の加水分解と重縮合が促進されていると思われ る。C 前駆体粉体では, メタノール 50 重量\%と蒸留水 50 重量\%の混合溶媒中にそれぞれ硝酸アルミニウム $\left(\mathrm{Al}\left(\mathrm{NO}_{3}\right)_{3} \cdot 9 \mathrm{H}_{2} \mathrm{O}\right)$ を $1 \mathrm{~mol} / \mathrm{L}$, オルトケイ酸テトラエチル $\left(\mathrm{Si}(\mathrm{OEt})_{4}\right)$ を $2 \mathrm{~mol} / \mathrm{L}$ となるように溶解し, これらの二 液を所望の $\mathrm{Al}_{2} \mathrm{O}_{3}$ と $\mathrm{SiO}_{2}$ の組成比（モル比 $\mathrm{Al}: \mathrm{Si}=6: 2 ）$ になるように混合した。この混合溶液 $1 \mathrm{~L}$ をメタノール $750 \mathrm{ml}$ と $\mathrm{pH} 10$ に調整されたアンモニア水 $1500 \mathrm{ml}$ の混 合溶液にすばやく加えて激しく擋汼し, $\mathrm{Ha}$ および $\mathrm{Hb}$ 前 駆体粉体と同様の方法で加熱還流後, 沈殿物をろ過, 乾 燥して C 前駆体粉体を得た。すなわち, C 前駆体粉体で はアルミナ源にアルコキシドではなく水溶液中で強酸で ある硝酸塩を用いている点が大きな相違点である。

それぞれの前駆体粉体の加熱による結晶相の変化は, 差動型示差熱天科（理学電機製, ThermoPlus2 TG8120） と電気炉を用いて大気中で加熱し, 粉末 X 線回折装置 (理学電機製, RINT-2100HK/PC) により調べた。焼結性 の評価には, 前駆体粉体が合成方法によってはムライト 化する際に急激な体積収縮を伴い焼結体中に亀裂が導入 される可能性があることおよび仮焼を行わないと焼成時 の収縮率が $25 \%$ 以上と大きく工業的に制御が困難になる ことから, $\mathrm{Ha}$ 前駆体粉体では $950^{\circ} \mathrm{C} て ゙ ~ 1$ 時間, $\mathrm{Hb}$ と C 前駆体粉体では $1450^{\circ} \mathrm{C}$ で 1 時間仮焼してムライト化さ せた後, それぞれの原料に窒化ケイ素製のボールとエ夕 ノールを加えて振動ミル (中央化工機製) で解砕した。 そして, これらの原料粉体を $30 \mathrm{MPa}$ の圧力で予備成形 後, $200 \mathrm{MPa}$ の圧力で静水圧成形して成形体を作製した。 成形体のかさ密度はノギスと重量より算出し，1570～ 
$1650^{\circ} \mathrm{C}$ で各 4 時間焼成した時のかさ密度は，水を用いた アルキメデス法により評価した。昇温時の収縮率の測定 は高純度アルミナを標準資料に用いた示差式高精度熱膨 張計（理学電機製, DRC-1）を用い大気中で $10^{\circ} \mathrm{C} / \mathrm{min}$ に て焼成温度まで昇温し， $1650^{\circ} \mathrm{C} 4$ 時間保持にて行った。

原料粉体の比表面積は窒素吸着による比表面積測定装 置（カルロ・エルバ製ソープトマチック 1800）を用いて 求め, アルミナ含有量は蛍光 $\mathrm{X}$ 線分析装置（理学電機製 ZSX), 不純物の定性, 定量分析はプラズマ発光分光分析 装置（島津製作所製 ICPS2000）にて測定した。ムライト の格子定数は粉末 X 線回折装置により測定した。すなわ ち，金属シリコンを内部標準として $\mathrm{Cu}-\mathrm{K} \alpha$ 線を用い，ム ライトの(401), (041), (002)のピークから最小二乗法によ り算出した。焼結体の微構造は, 鏡面に仕上げた研磨面 をムライトの粒径や形状を観察するために $1500^{\circ} \mathrm{C}$ で 15 分間熱処理をした熱エッチング面とムライトの粒界に存 在するガラス相の形骸を観察するためにフッ化水素酸 $1 \%$ 水溶液中に $0{ }^{\circ} \mathrm{C} て ゙ 24$ 時間処理した化学エッチング面を 日本電子製 $\mathrm{T} 200$ 型走査型電子顕微鏡を用いて観察した。 強度試験は電気炉を組み込んだ精密万能試験装置（島津 製作所製オートグラフ DCS-2000）を用い大気中 3 点曲 げ法により行い，室温から $1400^{\circ} \mathrm{C}$ の温度範囲でクロス ヘッド速度 $0.5 \mathrm{~mm} / \mathrm{min}$ で各試料につき 3 本以上測定し た。高温での曲げ強度法を用いた塑性変形の比較は $1300^{\circ} \mathrm{C}$ で負荷速度を $0.01 \mathrm{~mm} / \mathrm{min}$ にて行った。高温での クリープ特性の評価は $100 \times 20 \times 5 \mathrm{~mm}$ のプレートを両サイ ドをドッグボーン状に加工し，中央部に $20 \mathrm{~mm}$ 間隔で $5 \mathrm{~mm}$ 程度の突起を付与した試験片を用い, 大気中 $1400^{\circ} \mathrm{C}$ で引張法により行った[20]。

\section{3. 実験結果および考察}

\section{1 ムライト前駆体の結晶化過程}

仮燒前の $\mathrm{Ha}, \mathrm{Hb}$ および $\mathrm{C}$ ムライト前駆体粉体は，い ずれも粉末 X 線回折では非晶質であった。これらのムラ イト前駆体粉体の $1350^{\circ} \mathrm{C}$ までの示差熱分析結果を Fig. 1 に示す。いずれの粉体も $500^{\circ} \mathrm{C}$ 以下では前駆体調製時に 残存した有機物の分解などによる吸熱あるいは発熱ピー クが観察された。一方， $500^{\circ} \mathrm{C} よ り$ 高温では，Ha 前駆体 粉体の場合 $980^{\circ} \mathrm{C}$ 付近にのみ発熱ピークが認められ, $\mathrm{Hb}$ と $\mathrm{C}$ 前駆体粉体では $980^{\circ} \mathrm{C}$ 付近と $1250^{\circ} \mathrm{C}$ 付近にそれぞ

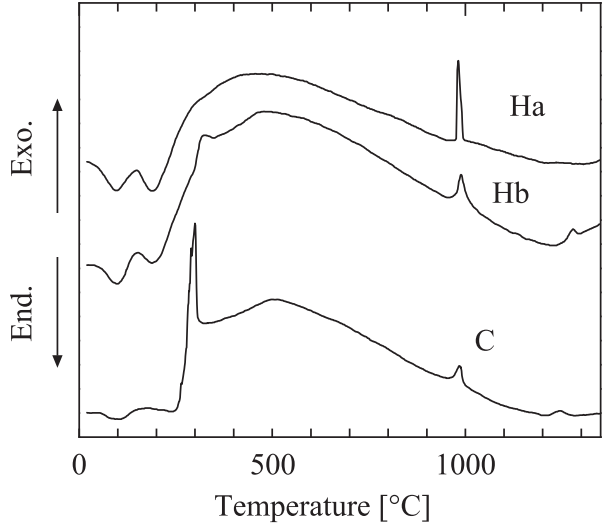

Fig. 1 DTA curves for three types of precursor powders with nominal composition of $3 \mathrm{Al}_{2} \mathrm{O}_{3} \cdot 2 \mathrm{SiO}_{2}$

れ発熱ピークが観察された。これらの発熱反応の前後で 急冷して粉末 X 線回折により結晶相の同定を行った結 果を Fig. 2 に示す。 Ha 前駆体粉体では $980^{\circ} \mathrm{C}$ 付近の発熱 ピークが非晶質からムライトと Al-Si スピネルと呼ばれ る中間相に結晶化するピークであることがわかった。一 方, $\mathrm{Hb}$ 前駆体粉体と $\mathrm{C}$ 前駆体粉体では, $980^{\circ} \mathrm{C}$ 付近の発 熱ピークが非晶質から Al-Si スピネル相の結晶化に, $1250^{\circ} \mathrm{C}$ 付近の発熱ピークがムライト相の結晶化に相当す ると考えられた。

これらの前駆体粉体の結晶化挙動の差異については, 以下のように考察した。まず, Ha 前駆体粉体については $\mathrm{pH} 7$ 付近での加水分解であることから, 加水分解速度が 遅い $\mathrm{Si}(\mathrm{OMe})_{4}$ と加水分解速度の早い $\mathrm{Al}\left(\mathrm{OPr}^{\mathrm{i}}\right)_{3}$ の加水分 解反応の進展の差が比較的小さいと推測される [19]。そ して，この前駆体粉体では還流中に Al(-O-Si-O-Al-O-Si-) を含有するシロキサン結合が形成され, $980^{\circ} \mathrm{C}$ 付近でム ライト化が進む噴霧熱分解により調製された粉体に近い 均質性を有していると思われた[19]。一方，鈴木らは金 属アルコキシドを用いて厳密に加水分解条件を制御し調 製したムライト前駆体では, $\mathrm{Si}(\mathrm{OEt})_{4}$ を部分的に加水分 解させてから $\mathrm{Al}\left(\mathrm{OPr}^{\mathrm{i}}\right)_{3}$ と混合して反応させることによ り，分子レベルで酸素を介して共重合した均質な前駆体 が調製できるため $900^{\circ} \mathrm{C}$ の低温でムライト化反応が進む ことを示した[16]。以上のことから，前駆体粉体の調製 方法が，得られる粉体の組成均質性や凝集性あるいは粒

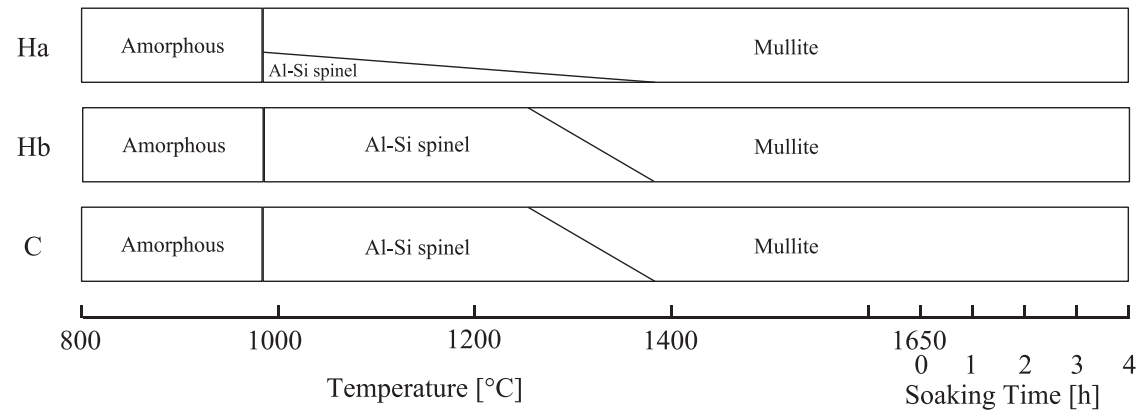

Fig. 2 Change in crystalline phases in the calcined precursors with temperature 
径などの粉体特性に大きな影響をおよぼし，結果として その後の焼結性や機械的特性に影響する可能性が高いと 思われた。

一方，ムライト前駆体の結晶化過程については合成方 法の違いによる前駆体中の $\mathrm{Al}$ の配位数が大きく関係して いると考える。中間層といわれるスピネル相は四配位と 六配位のアルミニウム酸素多面体から構成されており, 欠陥が無秩序に入った欠陥スピネル構造を有している。 これに対しムライトは複雑な結晶構造を有しており，そ の平均結晶構造は $\mathrm{c}$ 軸に沿って平行に $\mathrm{AlO}_{6}$ 八面体鎖が 並んでいて，この八面体鎖同士を四面体 $\mathrm{AlO}_{4}$ と $\mathrm{SiO}_{4}$ が 架橋しているといわれている[21]。すなわち， $\mathrm{AlO}_{6}$ 八面 体が鎖状に結合した構造を形成しやすい前駆体がムライ ト化しやすいと考えられる。

Okada らは, 硝酸アルミニウム 9 水和物 $\left(\mathrm{Al}\left(\mathrm{NO}_{3}\right)_{3} \cdot 9 \mathrm{H}_{2} \mathrm{O}\right)$ とオルトケイ酸テトラエチルをエタノール中に溶解混合 し，室温および $40 \sim 60^{\circ} \mathrm{C}$ で 5 日間熟成し， $60^{\circ} \mathrm{C}$ に設定 した恒温槽で 4 週間かけてゲル化させた前駆体の $1000^{\circ} \mathrm{C}$ におけるムライト化反応を詳細に調べた。その結果，熟 成温度により生成するムライトとスピネルの比率が異な り，60 $\mathrm{C}$ で熟成したものがもっともムライトが多いと報 告している[17]。これらの結果は，ムライトの結晶化温 度が組成の均質性だけでなく合成方法や条件による $\mathrm{Al}$ の 配位数が関係していることを示唆している。すなわち, $\mathrm{AlO}_{6}$ 八面体が鎖状に連なる前駆体構造が生成しやすい多 量の蒸留水で加水分解した $\mathrm{Ha}$ 前駆体において, もっと も低温でムライト化したものといえる。

\section{2 焼結特性におよぼす原料粉体特性の影響}

焼結特性の評価には, $\mathrm{Ha}, \mathrm{Hb}, \mathrm{C}$ 前駆体粉体それぞれを 異なる温度で仮焼および粉砕して用いた。これらの原料 粉体のアルミナ含有量と比表面積を Table 1 に示す。い ずれの原料粉体のアルミナ含有量も目的とした $60 \mathrm{~mol} \%$ に近い值を示した。仮焼条件は前駆体粉体がムライト化 し，収縮率が $20 \%$ 程度を示す温度，すなわち $\mathrm{Ha}$ 前駆体
粉体では $950^{\circ} \mathrm{C}$ で 1 時間, $\mathrm{Hb}$ と $\mathrm{C}$ 前駆体粉体ではそれ ぞれ $1450^{\circ} \mathrm{C} て ゙ 1$ 時間行った。Fig. 3 にそれぞれの前駆体 粉体を仮焼粉砕した原料粉体の透過型電子顕微鏡による 観察結果を示す。Ha 前駆体粉体を仮焼および粉砕した原 料粉体は粒度分布が広くナノ粒子が粗に凝集しているよ うに観察される。これに対し， $\mathrm{Hb}$ と C 前駆体粉体を仮 焼および粉砕した原料粉体は, Ha 原料粉体と比べて粒子 径が大きく比較的結晶性の高い粒子であることがわかる。 一方, いずれの原料粉体の比表面積も $30 \mathrm{~m}^{2} / \mathrm{g}$ 程度であ り, 大きな違いは認められなかった。すなわち, 焼結に 対する駆動力の違いはないものと思われた。しかし，ア ンモニア水で加水分解した $\mathrm{Hb}$ および $\mathrm{C}$ 前駆体粉体は $1450^{\circ} \mathrm{C}$ で仮焼したにもかかわらず，高い比表面積を示し たともいえる。これら二つの前駆体粉体の比表面積が高 温で仮焼したにもかかわらず高い比表面積であったのは, 組成が比較的均質であり仮焼途中で均質にムライト化し たために高温での仮焼でも粒成長しなかったものと考え られる[22]。

次に, これら 3 種類の原料粉体を成形し, $1650^{\circ} \mathrm{C}$ まで の昇温および保持した場合の収縮率の変化を Fig. 4 に示 す。いずれの原料粉体を用いて成形した試料の成形体密 度は $\mathrm{Ha}$ が $1.52 \mathrm{~g} / \mathrm{cm}^{3}, \quad \mathrm{Hb}$ が $1.51 \mathrm{~g} / \mathrm{cm}^{3}, \mathrm{C}$ が $1.53 \mathrm{~g} / \mathrm{cm}^{3}$ とほぼ同じ值を示した。これらの昇温時の収縮率の変化 は仮焼温度が大きく異なるにもかかわらず, $1450^{\circ} \mathrm{C}$ 付近 から収縮をし始めて $1500^{\circ} \mathrm{C}$ 以上で著しく収縮した。こ れは，調製したいずれの原料粉体においても $1500^{\circ} \mathrm{C}$ 以 下の低温では完全にムライト化しておらず， $1500^{\circ} \mathrm{C}$ 以上 で残留した非晶質相の粘性流動により粒子の再配列と成 長が急激に進行したためと思われる $[23] 。 1650^{\circ} \mathrm{C}$ での保 持において, $\mathrm{Hb}$ と $\mathrm{C}$ 前駆体からの焼結体では試料の収 縮はほぼ終了したのに対して, Ha 前駆体からの焼結体で は $1650^{\circ} \mathrm{C}$ での保持中も緩やかに収縮が進んだ。 $\mathrm{Ha}$ 前駆 体粉体においては $\mathrm{Hb}$ 試料や $\mathrm{C}$ 試料と比較して $1650^{\circ} \mathrm{C}$ に 到達しても収縮を伴う焼結が完了していないことを示し

Table 1 Alumina content and specific surface area of the calcined precursor powders with different hydrolysis conditions and calcination temperatures

\begin{tabular}{|c|c|c|c|}
\hline Symbol & Calcination & $\mathrm{Al}_{2} \mathrm{O}_{3}$ content & Surface area \\
\hline $\mathrm{Ha}$ & $950^{\circ} \mathrm{C} \quad 1 \mathrm{H}$ & $71.6 \mathrm{wt} \%$ & $35.8 \mathrm{~m}^{2} / \mathrm{g}$ \\
\hline $\mathrm{Hb}$ & $1450^{\circ} \mathrm{C}$ & 71.5 & 33.9 \\
\hline $\mathrm{C}$ & $1450^{\circ} \mathrm{C}$ & 71.5 & 28.5 \\
\hline
\end{tabular}

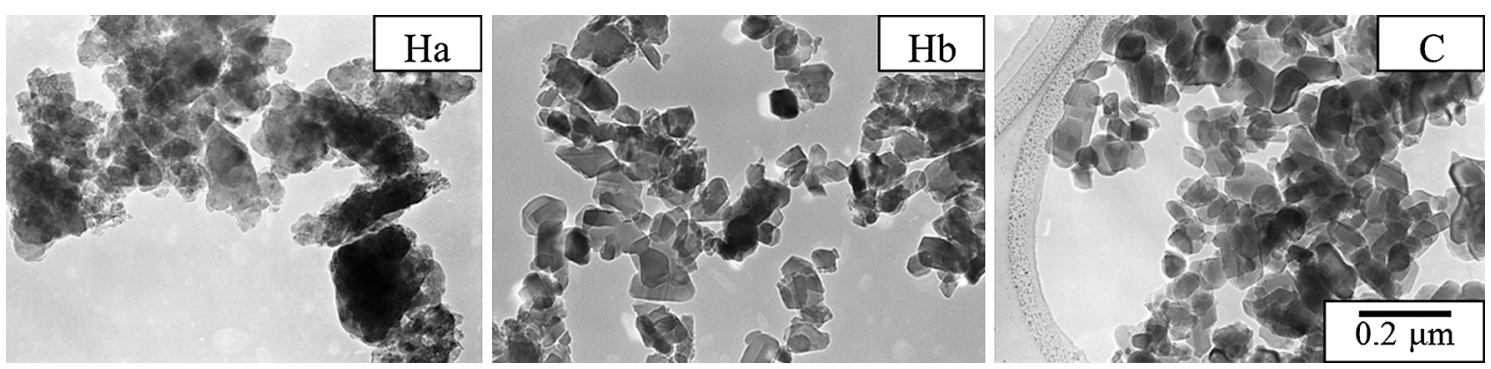

Fig. 3 Transmission electron micrographs for calcined precursor powders 


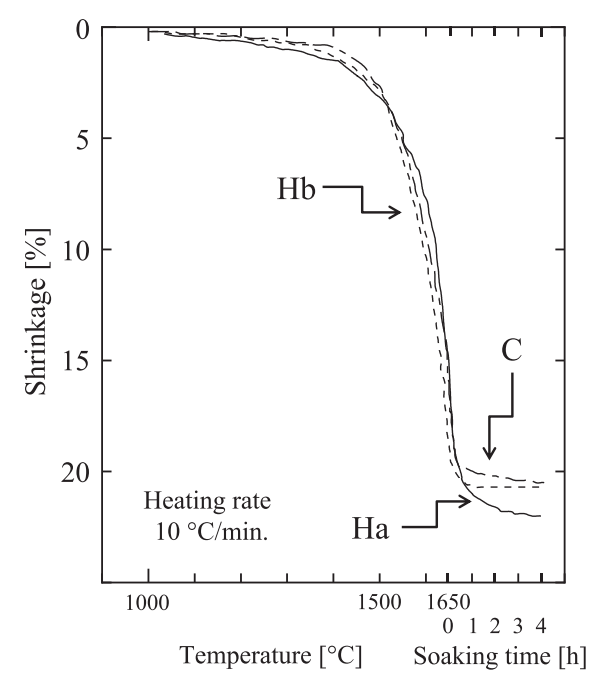

Fig. 4 Change in thermal shrinkage for the different types of precursor powders with stoiciometric mullite composition

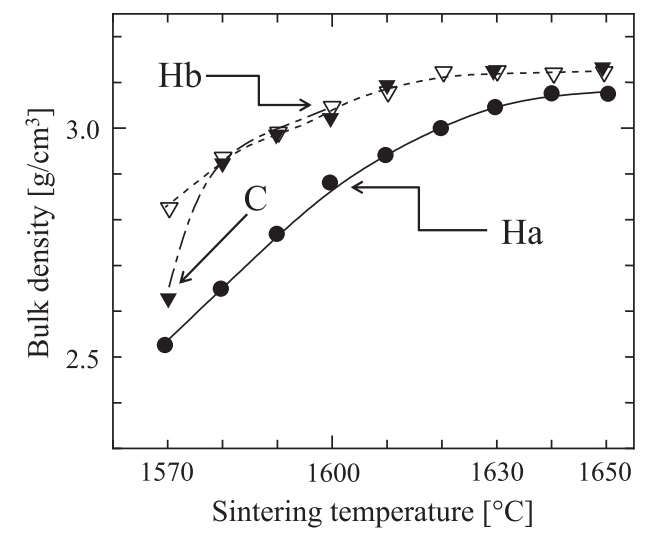

Fig. 5 Influence of sintering temperature on bulk density of the sintered ceramics from different precursors

ており，その後の焼結においても再配列とち密化に高温 と長い時間が必要であったためと考えられる。

Fig. 5 に各温度で 4 時間保持した場合のかさ密度の変 化を示す。 $\mathrm{Hb}$ と C 前駆体からの原料粉体は, $\mathrm{Ha}$ 前駆体 からの原料粉体と比較して明らかに低温でち密化が進み, $1630^{\circ} \mathrm{C} 4$ 時間でほほ $3.12 \mathrm{~g} / \mathrm{cm}^{3}$ と相対密度 $98 \%$ 以上の高 い值を示した。一方, $1650^{\circ} \mathrm{C}$ の保持中に収縮が断続的に 認められた $\mathrm{Ha}$ 前駆体からの原料粉体でも， $1650^{\circ} \mathrm{C} 4$ 時 間保持の焼結条件で $3.08 \mathrm{~g} / \mathrm{cm}^{3}$ と相対密度 $97 \%$ に高密度 化した。これらの結果は Fig. 6 に示した焼結体の微構造 観察より次のように考察が可能である。すなわち, 熱エッ チング面の観察では $\mathrm{Hb}$ 前駆体粉体からの焼結体中のム ライト粒子は Ha 前駆体粉体からのムライト粒子より若 干大きく成長している。さらに化学エッチング面の観察 結果より，粒界に存在するカラス相の量が $\mathrm{Hb}$ 前駆体粉 体からの焼結体の方が Ha 前駆体粉体の場合より多く生 成していることが観察された。この結果はガラス相の量 により焼結特性が異なり, $1650^{\circ} \mathrm{C}$ 保持では $\mathrm{Ha}$ 前駆体粉 体からの焼結体は収縮を伴う焼結ステージであるのに対 して, $\mathrm{Hb}$ と C の前駆体粉体からの焼結体は終期焼結の
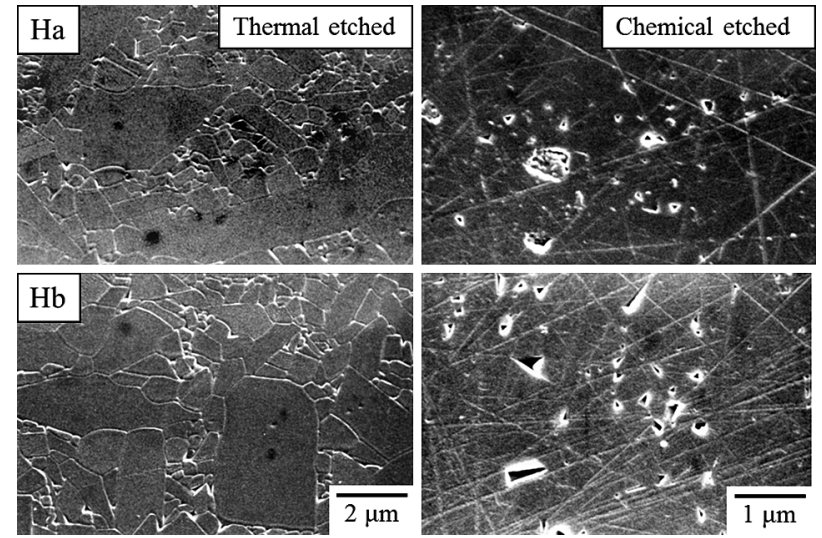

Fig. 6 Scanning electron micrographs for thermal $\left(1500^{\circ} \mathrm{C}\right.$ $15 \mathrm{~min})$ or chemical $\left(1 \% \mathrm{HFaq}\right.$ at $0^{\circ} \mathrm{C}$ for 24 hours $)$ etched surface of the sintered ceramics

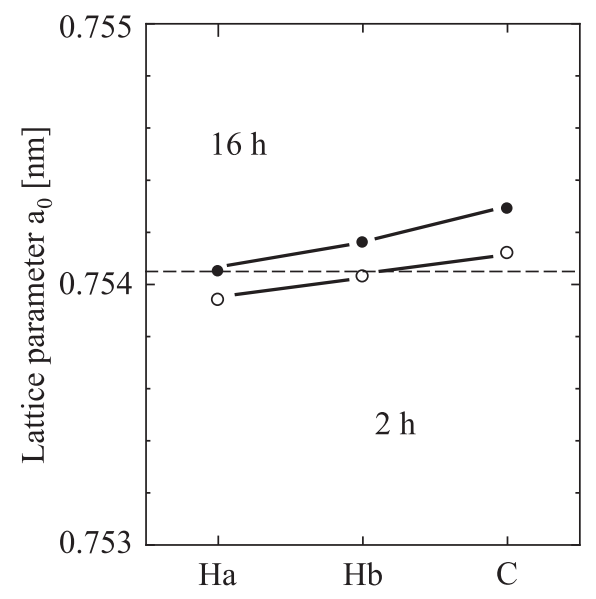

Fig. 7 Change in the lattice parameters, $a_{0}$ axis, of the mullite ceramics from different precursors, sintered at $1630^{\circ} \mathrm{C}$ for $2 \mathrm{hrs}$ and $16 \mathrm{hrs}$, respectively

\section{ステージであるといえる。}

上述の結果と考察を確認するため, それぞれの原料粉 体を成形して $1630^{\circ} \mathrm{C}$ で 2 時間と 16 時間焼成して得られ たムライト焼結体の格子定数 a の変化を Fig. 7 に示す。 図中の点線は, 化学量論組成のムライトの格子定数を示 している。ムライトの格子定数 a はムライトのアルミナ 含有量の増加とともに大きくなることが Cameron らによ り示されている[24]。本研究で用いた原料粉体に扔いて はバッチ組成がほぼ同じアルミナ含有量であるにもかか わらず，焼成時間 2 時間と 16 時間でいずれも $\mathrm{Ha}<\mathrm{Hb}<$ $\mathrm{C}$ の順序で格子定数が増加しており, 格子定数 $\mathrm{a}$ は 2 時 間より 16 時間の值が大きくなった。このような格子定数 の変化は原料粉体の組成の均質性あるいは焼結中の液相 生成量, すなわち前駆体粉体の合成方法に大きく関係し ており, 焼成時に均質性が劣っている $\mathrm{Hb}$ あるいは $\mathrm{C}$ 前 駆体では焼結中に液相が比較的多く生成したために焼結 が進行しやすく, 結果として焼結後に粒界に抢もにシリ カからなるガラス相が多く残存し， ムライト粒子中に含 まれるアルミナ含有量が高い值を示したと考えられる。 また, 長時間保持することにより格子定数 $\mathrm{a}$ は増加して 


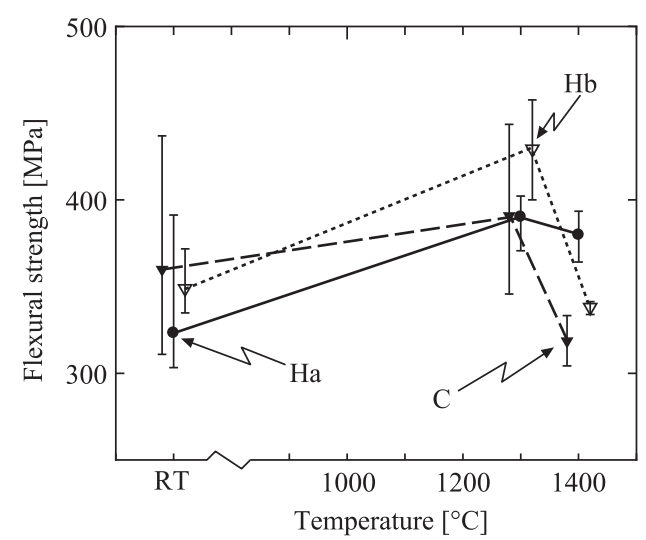

Fig. 8 Temperature dependence of the flexural strength of mullite ceramics from different precursors sintered at $1650^{\circ} \mathrm{C}$ for $4 \mathrm{hrs}$

おり，粒界のガラス相が高温長時間の焼結で増加してい ることから，状態図にしたがって焼結中に分解溶融反応 が生じて粒界に液相が生じることで焼結が促進されてい ることを裏付けている。

\section{3 機械的特性におよぼすムライト化の影響}

Fig. 8 に作製した焼成体の曲げ強度の温度依存性を示 す。室温における曲げ強度の值は前駆体の焼結性すなわ ち焼結後の密度に依存して抢り，もっとも液相が生成し やすい，すなわちもっとも組成が不均質な C 前駆体由来 の焼結体がもっとも大きな值を示した。一方，高温にお ける曲げ強度の值は組成が均質な $\mathrm{Ha}$ あるいは $\mathrm{Hb}$ 前駆体

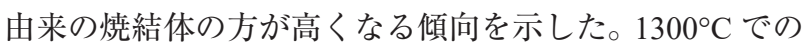
強度はいずれの試料においても室温強度に比較して高い 値を示した。 $1400^{\circ} \mathrm{C}$ では $1300^{\circ} \mathrm{C}$ と比較していずれの場 合も低下傾向を示したが，室温と比較した場合に組成が もっとも均質と思われる $\mathrm{Ha}$ 前駆体由来の焼成体ではほ とんど強度低下を示さなかった。このことは，焼結後の 残留ガラス相の量すなわち組成の均質性が反映された結 果であると考えられる。

さらに, $1300^{\circ} \mathrm{C}$ 強度試験におけるクロスヘッドスピー ドを Fig. 8 の条件の $1 / 50$ として測定した荷重－変位（応 カーひずみ) 曲線を Fig.9 に示す。Ha 前駆体由来の焼結 体はほほ直線的に試料に荷重が負荷されて破断している のに対して, $\mathrm{Hb}$ と $\mathrm{C}$ 前駆体由来の焼結体は破断直前に 線形から非線形に変化し, 塑性変形量はもっとも不均質 と思われる C 前駆体由来の焼結体がもっとも大きいこと がわかった。この結果はアルミナ含有量が $60 \mathrm{~mol} \%$ より もシリカに富む組成で観察された高温での応力緩和挙動 と同様であり，焼結中の液相生成量の違い，すなわち残 存ガラス相の量と焼結後のムライト組成の違いを反映し ていると考えられる[13]。

しかし，スピネル相を経由してムライト化した $\mathrm{Hb}$ 前

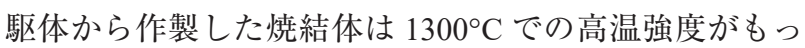
とも高く, 低速での強度評価において塑性変形の量も比 較的少なかった。すなわち, Hb 前駆体粉体は組成が比較 的均質で焼結中に適度に液相を生成したことにより,ち密

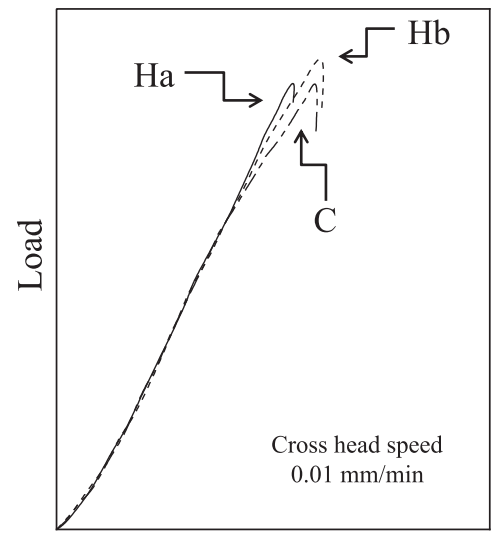

Deflection

Fig. 9 Load-deflection curves for mullite ceramics from different precursors sintered at $1650^{\circ} \mathrm{C}$ for $4 \mathrm{hrs}$

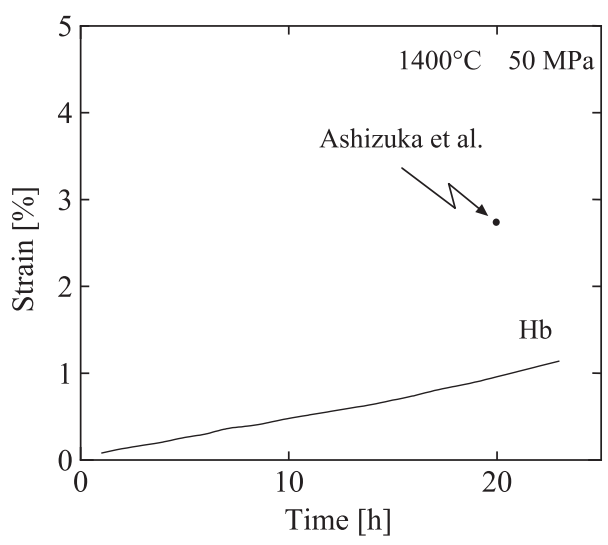

Fig. 10 Typical creep curve at $1400^{\circ} \mathrm{C}$ under $50 \mathrm{MPa}$ for mullite ceramics from $\mathrm{Hb}$ precursor sintered at $1650^{\circ} \mathrm{C}$ for $4 \mathrm{hrs}$

化とともに高温での機械特性が良好であった。そこで, $\mathrm{Hb}$ 前駆体から作製した焼結体の高温での機械特性をさら に詳細に調べた。方法は室温強度より低い強度值を示し た $1400^{\circ} \mathrm{C} に$ におる引張クリープにおける時間と歪の関 倸を測定し，その結果を Fig. 10 に示す。その結果， Hb 前駆体からの焼結体の歪量はこれまでに報告された化学 量論組成のムライトセラミックスの歪量と比較して約 $1 / 3$ と小さい值を示した[24]。この理由を調べるため, プラ ズマ発光分光分析法により本研究で調製した原料粉体の 組成を分析した。その結果, 測定した不純物 $\left(\mathrm{Na}_{2} \mathrm{O}\right.$, $\left.\mathrm{K}_{2} \mathrm{O}, \mathrm{MgO}, \mathrm{CaO}\right)$ の総量が $100 \mathrm{ppm}$ 以下と非常に少ない ことに加えて, 前駆体粉体の調製や仮焼方法を含めたプ ロセッシングの最適化により, 原料粉体の組成の均質性 を高めることが可能であった。その結果，焼結後に残留 するガラス相の量を比較的低く抑えたことに加え, $1400^{\circ} \mathrm{C}$ でのガラス相の粘性低下が少なかったことで歪を小さく 抑えられたものと考えられる。

\section{4. 結 論}

焼結後に微量のガラス相が残存する化学量論組成のム ライトに拀いて，ムライト化に至る反応の異なる前駆体 粉体を調製し, 前駆体粉体の調製方法の違いが焼結性と 
機械的特性におよぼす影響について調べた。その結果,

以下の結論が得られた。

（1）前駆体の調製方法は得られた粉体の組成均質性や凝 集性，あるいは粒径などの粉体特性に影響をおよぼ す。

（2）ムライト前駆体の結晶化過程におよぼす合成方法の 影響は，前駆体中の $\mathrm{Al}$ の配位数が関係している。

（3）均質性に劣る前駆体ほど焼結中の液相量が多いため ち密化が進行しやすく, 低温での強度が高いことが わかった。

（4）組成の均質性が劣る合成方法により調製された前駆
体から作製したセラミックスの方が高温での塑性変 形量は大きくなる傾向を示した。

（5） $\mathrm{Hb}$ 前駆体から作製した化学量論組成ムライトセラ

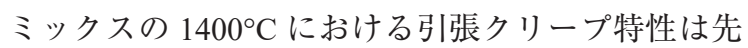
行文献のデータと比較して優れており, 高温構造材 料として期待できる。

[謝辞] 本研究を実施するにあたり, 産業技術総合研究所 中部センター神崎修三元所長, 元北興化学工業株式会社 御立千秋氏より, 貴重なご助言, ご協力を賜った。ここ に記して感謝の意を表します。

\section{References}

[1] S. Kondo, S. Suzuki, S. Sato, Mullite porcelain; 1, Dainippon Yogyo Kyokai Zasshi 48 (1940) 261-271.

[2] C. O. Hulse, J. A. Pask, Analysis of deformation of a fireclay refractory, J. Am. Ceram. Soc. 49 (1966) 312-318.

[3] J. Kreglo Jr., W. Smothers, Creep characteristics of selected high-alumina brick, J. Metals 19 (1967) 20-22.

[4] W. Wang, Z. Shi, Z. Wang, S. Wang, Phase transformation and properties of high-quality mullite ceramics synthesized using desert drift sands as raw materials, Mater. Lett. 221 (2018) 271-274.

[5] R. Reddy, K. Gopal, Y. Ahammed, K. Narasimhulu, L. Reddy, C. Reddy, Correlation between optical electronegativity, molar refraction, ionicity and density of binary oxides, silicates and minerals, Solid State Ion. 176 (2005) 401-407.

[6] J. Fenstermacher, F. Hummel, High-temperature mechanical properties of ceramic materials: IV, sintered mullite bodies, J. Am. Ceram. Soc. 44 (1961) 284-289.

[7] T. Mitsudome, I. Furusato, H. Nagai, Mullite Ceramics from High Purity Kaolin, Mullite 2, Uchida Rokakuho, Tokyo (1987) pp. 129-143.

[8] H. Yamada, S. Kimura, Studies on the nature of the mullite formed from co-precipitate of alumina and silica gels, Yokyo-shi 70 (1962) 99-105.

[9] O. Seri, T. Nishida, Y. Wada, Y. Osafune, Preparation of mullite powder by corrosion synthesis, J. Jpn. Soc. Powder Metallurgy 59 (2012) 391-393.

[10] K. S. Mazdiyasni, L. M. Brown, Synthesis and mechanical properties of stoichiometric aluminum silicate (mullite), J. Am. Ceram. Soc. 55 (1972) 548-552.

[11] P. A. Lessing, R. S. Gordon, K. S. Mazdiyasni, Creep of polycrystalline mullite, J. Am. Ceram, Soc. 58 (1975) 149.

[12] P. C. Dokko, J. A. Pask, K. S. Mazdiyasni, High-temperature mechanical properties of mullite under compression, J. Am. Ceram. Soc. 60 (1977) 150-155.

[13] T. Kumazawa, S. Kanzaki, S. Ohta, H. Tabata, Influence of chemical composition on the mechanical properties of $\mathrm{SiO}_{2}$ $\mathrm{Al}_{2} \mathrm{O}_{3}$ ceramics, J. Ceram. Soc. Jpn. 96 (1988) 85-91.
[14] Y. Hirata, H. Minamizono, K. Shimada, Sinterability of fine $\mathrm{SiO}_{2}-\mathrm{Al}_{2} \mathrm{O}_{3}$ powders derived from metal alkoxide, Yogyo Kyokai Shi 93 (1985) 475-478.

[15] H. Suzuki, H. Saito, Processing of the fine mullite powder from metal-alkoxides and its sintering, Yogyo Kyokai Shi 95 (1987) 697-702.

[16] H. Suzuki, Y. Tomokiyo, Y. Suyama, H. Saito, Preparation of ultra-fine mullite powder from metal alkoxides, J. Ceram. Soc. Jpn. 96 (1988) 67-73.

[17] K. Okada, N. Otsuka, Characterization of the spinel phase from $\mathrm{SiO}_{2}-\mathrm{Al}_{2} \mathrm{O}_{3}$ xerogels and the formation process of mullite, J. Am. Ceram. Soc. 69 (1986) 652-656.

[18] K. Hamano, T. Sato, Z. Nakagawa, Properties of mullite powder prepared by coprecipitation and microstructure of fired bodies, Yogyo Kyokai Shi 94 (1986) 818-822.

[19] S. Mitachi, N. Kaneko, S. Kanzaki, Characterization of $\mathrm{SiO} 2-\mathrm{Al} 2 \mathrm{O} 3$ Powders Prepared From Metal Alkoxides, Ceramic Transactions, Vol. 6, Am. Ceram. Soc. Inc., Ohio (1990) pp. 275-286.

[20] T. Ohji, Y. Yamauchi, Long-term tensile creep testing for advanced ceramics, J. Am. Ceram. Soc. 75 (1992) 23042307.

[21] T. Ban, K. Okada, Structure refinement of mullite by the rietveld method and a new method for estimation of chemical composition, J. Am. Ceram. Soc. 75 (1992) $227-$ 230.

[22] H. Suzuki, M. Shimizu, H. Kamiya, M. Takahashi, T. Ota, Preparation of fine mullite powders with high surface area by agglomeration control of alkoxide-derived precursor sol, J. Soc. Powder Technol., Japan 34 (1997) 170-175.

[23] I. Aksay, J. Pask, Stable and metastable equilibria in the system $\mathrm{SiO}_{2}-\mathrm{Al}_{2} \mathrm{O}_{3}$, J. Am. Ceram. Soc. 58 (1975) 507-512.

[24] W. E. Cameron, Composition and cell dimensions of mullite, Am. Ceram. Soc. Bull. 56 (1977) 1003-1007.

[25] M. Ashizuka, T. Okuno, Y. Kubota, Creep of mullite ceramics, J. Ceram. Soc. Jpn. 97 (1989) 662-668. 